\title{
AZ ÖNSZERVEZŐDŐ CSOPORTOK SZEREPE AZ UGANDAI PÉNZÜCYI RENDSZERBEN
}

\author{
VASA LÁSZLÓ - VIDA IMRE
}

\section{Bevezetés}

Az alulról szerveződő, önkéntes együttmüködésen alapuló, általában egy-egy falusi, kerületi közösség, piac, foglalkozás köré szerveződő csoportok jelentős szerepet játszanak - elsősorban a legszegényebb rétegekre fókuszálva - a szubszaharai Afrika országainak pénzügyi rendszereiben. Ennek oka, hogy a hagyományos, formális pénzintézetek számára ennek a célcsoportnak a hitelezése több szempontból sem lehetséges (földrajzi lefedettség hiánya, az ügyfelek elérésének nehézségeiböl fakadó magas tranzakciós költségek és ami a legfontosabb: a fedezetek és garanciák teljes hiánya). A szövetkezeti mozgalom, illetve a bangladesi Grameen modell ${ }^{1}$ sikerei nyomán a részben vagy teljesen önszerveződésen alapuló mikrofinanszírozási szervezetek elterjedtek a kontinensen. Erre az új folyamatra a pénzügyi szabályozó rendszereknek is reagálniuk kellett (Popp et al, 2019), már csak azért is, mert a mikrofinanszírozás - mely korántsem csak hitelezést, hanem betétgyüjtést, biztosítást és a pénzügyi írástudatlanság csökkentését (Tarrósy, 2010) is jelenti - a kormányzati szegénység elleni küzdelem és vidékfejlesztési programok fontos pillérévé vált (Oshora-Magda, 2019). Tanulmányunkban az önszerveződő csoportok szerepét vizsgáljuk meg az ugandai példán keresztül, a hagyományos adatbázisokon és a szakirodalmon kívül az Open Source Intelligence módszertan eszköztárát is igénybe véve.

\section{Az ugandai pénzügyi szektor}

Az ugandai pénzügyi szektor kereskedelmi bankokon, hitelintézeteken, betétgyüjtő mikrofinanszírozási intézményeken (Microfinance Deposit Taking Institution MDI), valamint takarék- és hitelszövetkezeti szervezeteken (Savings and Credit Cooperative Organization - SACCO) alapul, 25 kereskedelmi bankot, négy hitelintézetet, öt MDI- $\mathrm{t}^{2}$, valamint 2000 SACCO-t és mikrofinanszírozási szervezetet foglal magában. A szolgáltatók ilyen sokfélesége ellenére, vagy éppen emiatt a pénzügyi szolgáltatásokhoz való hozzáférés továbbra is kihívást jelent, különösen a vidéki lakosság számára. A kereskedelmi bankok, amelyek az ország legnagyobb pénzintézetei és hitelezői, megbízhatónak és likvidnek számítanak. Együtt a teljes magánszektor hiteleinek $95 \%$-át kezelik. A maradékon a többi intézmény - ideértve a SACCO-kat és a többségében civil szervezeti alapú mikrofinanszírozási intézmé- 
nyeket - osztoznak. A kereskedelmi bankok megfelelő hozamot realizálnak, nem teljesítő hiteleik 4-5\% körül vannak, ami meglehetösen jó érték (BoU, 2017). Az 9,9 billió UGX teljes likvid eszközével, vagyis az összes eszköz 37\%-ával a kereskedelmi bankok elegendő likviditással rendelkeznek.

A pénzintézetek hagyományos, fiókokon alapuló fizikai jelenléte korlátozott az ugandai vidéki területeken, de a mobilbankos ügynökök nagyszámú hozzáférési pontot kínálnak. A Nemzetközi Valutaalap pénzügyi hozzáférési felmérése szerint 2016-ban ${ }^{4}$ jóval alacsonyabb, mint Kenyában $(5,43)$ vagy Ruandában $(6,16)$. Ugandában tehát a vidéki lakosság korlátozott hozzáféréssel rendelkezik a bankfiókokhoz, amelyek $70 \%$-a városi területeken található. A mobilbanki ügynöki hálózat lefedettsége meszsze meghaladja a hagyományos bankokét; míg a lakosság mindössze 16\%-ánál állt rendelkezésre banki szolgáltató pont $1 \mathrm{~km}$-es körzetben, addig 2015-ben a lakosság 54\%-ánál létezett mobil pénzforgalmi pont (Republic of Uganda, 2017). Az banki ügynöki tevékenység egészen a közelmúltig nem volt megengedett, ám 2017 júliusában az Ugandai Nemzeti Bank (Bank of Uganda/BoU), amely a bank- és biztosítási szabályozó hatóság, végül jóváhagyta a pénzintézetekről szóló törvény módosítását a bankok ügynöki tevékenységének engedélyezését (Panturu, 2019).

A hitelügyletek gyakoriak, de elsősorban informális hitelezés formájában. Az FSD Uganda ${ }^{5}$ (2018) szerint az ugandaiak 46\%-a vett fel hitelt a felmérést megelőző 12 hónapban. Ugyanakkor a hitelfelvevők $90 \%$-a számolt be az informális hitelezésről: 37\%-uk a falusi megtakarítási és hitel egyesületeket (Village Savings and Loan Associations, VSLA), 14\%-uk önkéntes megtakarítási csoportokat (Rotating Savings and Credit Associations, ROSCA), 12\%-uk temetkezési közösségeket ${ }^{6}$ használt hiteligényei fedezésére, 25\%-uk áruhitel segítségével vásárolt, 2\%-uk pedig uzsorásra támaszkodott. A hitelfelvevőknek csak 10\%-a vett fel kölcsönt hivatalos hitelezőktől, például kereskedelmi bankoktól, mikrofinanszírozási intézményektől, hitelintézetektől vagy hivatalos SACCO-tól. A Global Findex $2017^{7}$ felmérésben a felnőttek $22 \%$-a számolt be arról, hogy hitelt vett igénybe egy gazdaság vagy vállalkozás indításához, müködtetéséhez vagy bővítéséhez.

Az Ugandai Központi Bank (BoU, 2018) szerint a bankok száma a 2010/11-es 23-ról a 2018/19-re 33-ra nőtt, a 3. szintủ (betétgyüjtő mikrofinanszírozási) intézmények pedig háromról ötre. A 4-es szint félig formális és informális pénzügyi intézményekből állt, amelyek mintegy 1000 aktív SACCO-val, körülbelül 300 betéteket nem gyüjtő MFI-társasággal és több mint 70000 pénzügyi önsegítő csoportot jelentettek 2018-ban. Növekedtek az intézmények eszköz- és hitelportfóliói, amelyek 
várhatóan javítják a kisvállalkozások és a háztartások formális pénzügyi szolgáltatásokhoz való hozzáférését.

Uganda bankjainak túlnyomó része külföldi tulajdonban van, olyan nagy nemzetközi pénzügyi intézményekkel a háttérben, mint a Stanbic, a Citibank, a Barclays és a Standard Chartered. Számos helyi tulajdonú bankot is alapítottak, köztük a DFCU Bankot, a Crane Bankot és a Cerudebet.

Az 1990-es évek elejére a bankszektor tulajdonképpen négy, külföldi tulajdonú bankból állt (Standard Chartered, Standard Bank, Barclays és Baroda), valamint a két nagy hazai bankból (UCB és Co-op) állt; ez utóbbiak uralták ugyan a bankszektor 70 százalékát, viszont fizetésképtelenek voltak. 2005 végére a rendszer lényegesen kibővült, kialakultak a formális és az informális szektorok. A formális intézmények közé kereskedelmi bankok (Tier 1), a hitelintézetek (Tier 2), és 2004 óta a betétgyüjtő mikrofinanszírozási intézmények (Tier 3), valamint az Országos Társadalombiztosítási Alap (NSSF), a Postabank, a biztosítótársaságok, a Forex ügynökségek és a tőzsde tartozik. Az informális szektor a pénzkölcsönzők, a SACCO, az önkéntes megtakarítási csoportokat (Rotating Savings and Credit Associations, ROSCA) és a mikrofinanszírozási intézmények (MPI) széles köréből áll. Az informális pénzügyi intézmények tekintetében jelentős elörelépés történt ezen intézmények elérhetőségének bővítésében és a pénzügyi szolgáltatásokhoz való hozzáférés javításában, különösen a vidéki lakosság körében.

A pénzügyi szektor összes eszközállománya 45,81 trillió ugandai shillinget tett ki, vagyis Uganda GDP-jének 44,3 százalékára rúgott 2018. december végén. Amint az alábbiakban szemléltetjük (1. ábra), a pénzügyi szektort Bank of Uganda, mint központi bank által szabályozott bankszektor dominálja.

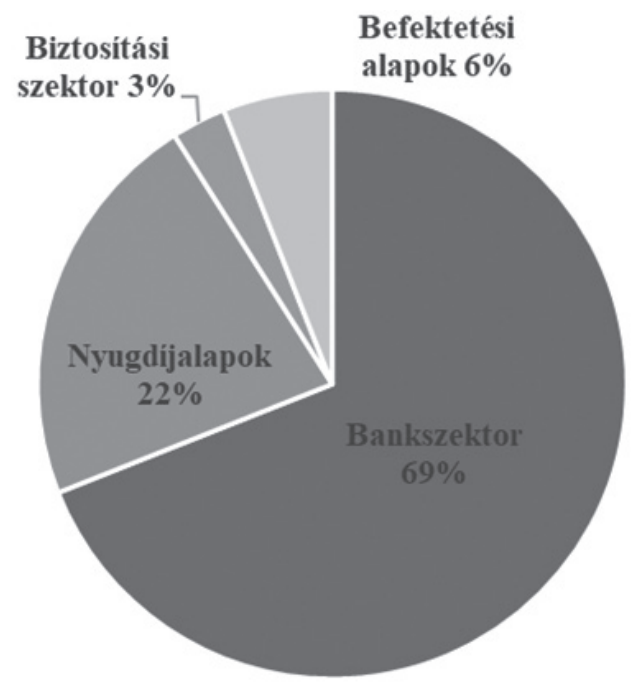

1. ábra: Az ugandai pénzügyi rendszer struktúrája. Forrás: Bank of Uganda, 2019 
Uganda bankszektora a kereskedelmi bankokat, hitelintézeteket betétgyüjtő mikrofinanszírozási intézményeket foglal magában. 2019 júniusának végén a kereskedelmi bankok a bankszektor 31,2 trillió shilling összes eszközértékének 95,2\%-át tették ki.

A kereskedelmi bankok többségének külföldi többségi tulajdonosa van (2. ábra), mely tény - tekintettel arra, hogy ezek többsége neves, nemzetközileg ismert bank - pozitívan hat a pénzügyi rendszer stabilitására, egyrészt a tőkeerős tulajdonosok, másrészt a világszínvonalú banküzemi kultúra meghonosítása miatt.

A kereskedelmi bankok által dominált pénzügyi közvetítési tevékenység viszont alacsony volumenủ színvonalú, korlátozott szerepet játszik a fejlesztés finanszírozásához szükséges források biztosításában. Az egyéb pénzügyi közvetítők száma korlátozott, kicsi és viszonylag hatástalan (Mallinguh - Zéman, 2018). Következésképpen csak korlátozott számú pénzügyi eszköz áll rendelkezésre megtakarítások mobilizálására, likviditáskezelésre és portfólió-diverzifikációra.

A nem jegybank által szabályozott mikrofinanszírozási tevékenység elterjedésének van egy, az eredeti szándékoktól eltérő oka is, melyre Pásztor hívta fel a figyelmet 2019-es, Afrika monetáris politikáival foglalkozó tanulmányában. Megállapítása szerint a betétek és a hitelkamatok állandóan magas kamatkülönbözete (spread) az afrikai országokat fenyegető jelentős, egyfajta belső kihívás. A magas hitelköltségek miatt a kölcsönfelvevők frusztrált helyzetbe kerülnek és gyakran jelentős politikai nyomás alakul ki a kamatlábak szabályozásának kapcsán. Azonban a monetáris politika átpolitizálódása eredményeképpen számos jól ismert kockázat is születik, amely a pénzügyi rendszer épségét és a hitelhez való hozzáférést veszélyezteti, az utóbbi pedig ilyen módon a magasabb kockázatot vállaló hitelfelvevőket. A tapasztalatok azt mutatják, hogy a kamatszabályozás gyakran kisebb hitelfelvevők (fogyasztók, kisvállalkozók és mezőgazdasági dolgozók) hitelfelvételi lehetőségeit szűkíti be és egyúttal tovább táplálja az eleve drágább informális hitelezést (Pásztor, 2019).

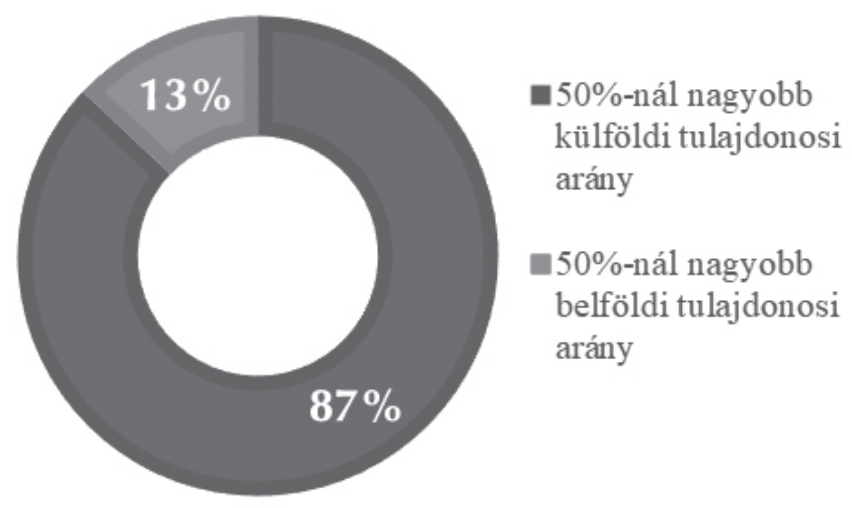

\2. ábra: Az ugandai kereskedelmi bankok tulajdonosi megoszlása, 2019. Forrás: Bank of Uganda, 2019 


\section{Pénzügyi tudatosság Ugandában}

A FinScope 2018-as felmérése szerint a pénzügyi müveltség alacsony szintjére utal az a tény, hogy az ugandai felnőttek $70 \%$ nem végzett középfokú tanulmányokat. A felmérés eredményei azt mutatják, hogy a felnőttek kevesebb, mint fele követi nyomon bevételeit és kiadásait, 44\%-uk nem kér tanácsot másoktól, és ha mégis, akkor elsősorban a családhoz és a barátokhoz fordulnak (FSD Uganda, 2018). Ugyanezen tanulmány megállapítja azt is, hogy - elsősorban a mobilfizetési rendszerek elterjedésének köszönhetően - 2006-hoz képest megduplázódott a formális pénzügyi intézményrendszerrel kapcsolatban lévő ugandaiak aránya, 2018-ra elérve az 58\%ot. (A formális és informális pénzügyi rendszert figyelembe véve ez az arány 78\%).

A pénzügyi rendszeren kívül rekedés a vidéki területeken igen jelentős. A rurális térségekben a felnőttek mintegy $25 \%$-a kívül reked a pénzügyi szolgáltatásokon, míg a városi területeken ez az érték csak 14\%. Ráadásul a városi felnőttek mindössze $10 \%$-a támaszkodik teljes mértékben az informális szolgáltatásokra, míg vidéki felnőtteknél ez a szám 23\%. Hasonlóképpen, a kisméretű mezőgazdasági háztartások is korlátozottan férnek hozzá a pénzügyi szolgáltatásokhoz. A szegényeket segítö tanácsadó csoport (csoport (Consultative Group to Assist the Poor, CGAP) ${ }^{8}$ nemzeti felmérése szerint az ugandai kistermelők csupán 10\%-ának van bankszámlája, 73\%-uk pedig mobil pénzforrásokat használt. A mezőgazdasági alapanyagok megvásárlásához a megkérdezett háztartások 93\%-a azonnali készpénzügyleteket említ, míg csak 7\%-uk rendelkezik olyan (leginkább szállítói) hitellel, amely későbbi fizetést tesz lehetővé (Anderson et al, 2016).

Az 1. táblázat bemutatja egyes pénzügyi szolgáltatások elterjedtségének mutatóit, melyből jól látszik, hogy a hagyományos, bankokon és az ott vezetett számlákon alapuló fizetési rendszerek már széleskörủ elterjedtségük előtt meghaladottá váltak, a mobilfizetési megoldások által. Ezek - éppen a formális pénzintézeti rendszer penetrációs problémái és az informális rendszerek kockázati tényezői miatt - igen

\begin{tabular}{l|l}
\hline Számlával rendelkező felnőttek & $59 \%$ \\
\hline Számlával rendelkező nők & $53 \%$ \\
\hline Számlával rendelkezők fiatal felnőttek (15-24 évesek) & $57 \%$ \\
\hline Pénzintézetnél számlával rendelkező felnőttek & $33 \%$ \\
\hline Mobil money számlával rendelkező felnőttek & $51 \%$ \\
\hline Pénzintézetnél megtakarításokkal rendelkező felnőttek & $13 \%$ \\
\hline Formális pénzintézetektől hitellel rendelkező felnőttek & $15 \%$ \\
\hline Barátok és család által hitelezett felnőttek & $46 \%$ \\
\hline Szegénységi mutató & $34 \%$ \\
\hline
\end{tabular}

\1. táblázat: Pénzügyi szolgáltatások elterjedtségének néhány mutatója Ugandában, 2017. Forrás: Demirgüç-Kunt, 2018 (The Global Findex Database 2017)

Vasa László - Vida Imre: Az önszerveződő csoportok szerepe... 
nagy népszerüségnek örvendenek rugalmasságuk, a könnyü hozzáférés és a problémamentes és olcsó mikrofizetési lehetőségek miatt.

\section{A mikrofinanszírozási szervezetek}

A mikrohiteleket többnyire nonprofit szervezetek nyújtják, amelyek üzleti és életviteli tanácsadással kombinálják a hitel folyósítását. A mikrohitel program az Egyesült Államokban elsősorban nőket, etnikai kisebbségeket, alacsony jövedelműeket és alulfoglalkoztatottakat vagy munkanélkülieket támogat. A kezdeményezés a helyi vállalkozói kapacitás növelését tüzi ki célul, illetve a közösségek gazdaságának erejét és munkahelyteremtő képességét kívánja növelni (Oláh et al, 2001). A különböző ázsiai államok afrikai szerepvállalásai között számos megoldást találunk, melyek a helyi közösségek vállalkozói képességeit is támogatják. India például jelentős forrásokat koncentrál a kapacitások megerősítésére, bővítésére, a humán erőforrás fejlesztésére (Tarrósy, 2016).

A világban három alapvető mikrofinanszírozási megközelítés azonosítható (Srinivasan-Sririam, 2003). Az első a bangladesi Grameen Bank módszertanán alapuló modell (Grameen-modell). A második az önsegélyező csoportok (self-help groups) modellje, amelyben a csoport közös megtakarításai jelentik a tagok számára elérhető hitelek forrását. A harmadik megközelítés központjában nem a csoport, hanem az egyén áll (individual banking modell). Ahogyan az 1. ábra mutatja, a három modell jellemzően eltérő piaci szegmensek, célcsoportok elérését biztosítja, és az idődimenziót bevonva egy fejlődési folyamatot is tükrözhet. A legszegényebbek a Grameen-modell szerint jutnak hitelhez, míg akiknek sikerül egy kicsit előbbre lépniük, önsegítő csoportokba szerveződhetnek, végül alkalmassá válnak - előbb mások kezességvállalása mellett, később önállóan is - arra, hogy egyénileg is kapcsolatba kerüljenek a finanszírozó intézménnyel (Imreh et al, 2007).

A mikrohitelezés módszertana nagyot és sok irányba fejlődött a Grameen Bank koncepciója óta. Változatos intézmények - például civil szervezetek (NGO), hitelegyesületek (Credit Unions), kis, közösségi bankok (Village Banking), garanciaszövetkezetek - alakultak annak érdekében, hogy a kis összegü hitelezés két fö kihívására: 1) alacsonyan tartani a tranzakciós költségeket, és 2) megtalálni a kockázatkezelés hitelfedezeten kívüli eszközeit, hatékony választ adjanak (Ledgerwood, 1999, Neszmélyi, 2016).

Az mikrofinanszírozási intézetek (MFI) kis összegü hiteleket nyújtanak elsősorban a banki szektor látókörén kívül eső, kis jövedelmü lakosságnak, általában alacsony szintủ hitelbiztosíték mellett. A mikrohiteleket kínáló civil szervezetek az 1970-es évek végétől nagy elismerést vívtak ki azzal, hogy képesek a mikrohiteleken keresztül elérni a szegényeket és javítani helyzetükön. Az MFI-k ma Afrika számos szegény háztartását szolgálják megtakarítási és hitelfelvételi lehetőségekkel ${ }^{9}$

Nehéz meghatározni a közösségi bankok és mikrofinanszírozási szervezetek számát Afrikában, mivel sokuk minden engedély nélkül, nem hivatalosan müködik, illetve sokszor csak kezdetleges, ám nagyon hatékony helyi, esetleg törzsi kezdeményezések- 
ről van szó. A fejlettebb afrikai országokban a kormányzatok próbálják szabályozni a piacot, legföképpen azért, hogy kiszürjék az uzsorásokat (Borbély, 2014).

\section{Tagsági alapú pénzügyi szolgáltatók}

A tagok tulajdonában lévő pénzügyi szolgáltatók (Financial Service Provider FSP), amelyeket közösségi alapú pénzügyi szervezeteknek is szoktak nevezni, heterogén

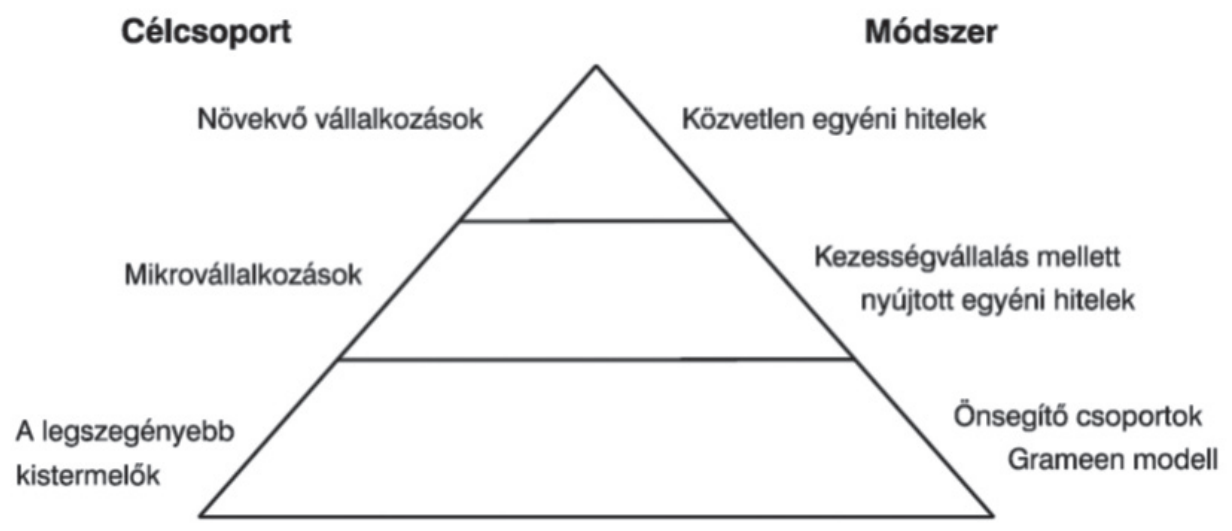

\3. ábra: A mikrofinanszirozás módszerei és az elérhetö célcsoportok.

Forrás: Imreh et al, 2007, Srinivasan-Sririam, 2003 alapján

\begin{tabular}{l|l|l}
\hline Formális & Félig formális & Informális \\
\hline Kereskedelmi bankok & Civil szervezetek (NGO-k) & $\begin{array}{l}\text { Közösségi bankok (village } \\
\text { bank) }\end{array}$ \\
\hline Fejlesztési Bankok & Hitelszövetkezetek & Önsegélyezö egyletek \\
\hline Takarékszövetkezetek & $\begin{array}{l}\text { Önszervezödö takarék- és } \\
\text { hitelszövetkezetek }\end{array}$ & $\begin{array}{l}\text { Pénzügyi szolgáltató szövet- } \\
\text { ségek }\end{array}$ \\
\hline $\begin{array}{l}\text { Nem-banki finanszírozási } \\
\text { intézmények }\end{array}$ & privát cégek & $\begin{array}{l}\text { ROSCA (Rotating Sav- } \\
\text { ings and Credit Association } \\
\text { önkéntes megtakarítási } \\
\text { csoportok) }\end{array}$ \\
\hline Pénzügyi vállalatok & $\begin{array}{l}\text { ASCA (Accumulated } \\
\text { Savings and Credit } \\
\text { Associations - Felhalmozó } \\
\text { Takarék- és Hitelszövet- } \\
\text { kezetek) }\end{array}$ \\
\hline Lízingcégek & Temetkezési egyesületek \\
\hline Biztosítók & & Egyéni hitelezök \\
\hline
\end{tabular}

2. táblázat: A mikrofinanszírozást nyújtó szervezetek három fö típusa.

Forrás: Churchill-Frankiewicz, 2006 
kategória, amely magában foglalja a hagyományos ROSCA-kat és a felhalmozó takarék-és hitelszövetkezetek (Accumulated Savings and Credit Associations - ASCA) ${ }^{10}$ a Pénzügyi Szolgáltatási Szövetségeket (Financial Service Association FSA) ${ }^{11}$, valamint a hivatalos szövetkezeteket és takarékpénztári és hitelszövetkezeteket (SACCO; másutt általában hitelszövetkezetként ismert), melyek állami szabályozása - az ugandai bankrendszer szerinti 4. szintủ pénzügyi szolgáltatókról ${ }^{12}$ lévén szó - nem megoldott: néhányat nyilvántartásba vettek és jellemzően nem túl szigorúan felügyelnek. Jelentős erőfeszítések történnek kis informális megtakarítási csoportok és falusi megtakarítási és hitel egyesületek (Village Savings and Loan Associations VSLA) létrehozására, amelyek hasonlóak az ASCA-khoz. Ezek alapján nem meglepő, hogy becslések szerint Afrikában a lakosság hét százaléka szövetkezetekhez tartozik. ${ }^{13}$

\section{Az önsegélyezö csoportok}

Az önsegélyező csoportok (Self-Help Groups, SHG) a felhasználók tulajdonában lévő, irányított és ellenőrzött nagyon kicsi szervezetek, amelyek sokkal inkább a szoros helyi kapcsolatokon alapulnak, mint a formális müködésen. Egy tipikus SHG-nek 15-30 tagja van (kivételesen legfeljebb 50), tagoktól körében végzett betétgyüjtéssel és tagoknak történő hitelezéssel foglalkozik (3. táblázat). Az SHG-k pénzügyi termékei általános jellegủek és átláthatóak: magukban foglalják a rendszeres megtakarításokat és egyszerü kölcsönöket a tagok számára; a hiteleket általában legfeljebb három hónapra, de a gyakorlat szerint inkább csak egy hónapra folyósítják. A távoli vidéki területek, amelyek nehezen elérhetőek, kiváló terjeszkedési lehetőség az SHG-k számára, betöltve a pénzügyi szolgáltatási vákuumot.

Az általunk felkeresett mikrofinanszírozási szakemberek, akik SHG-kat és MFIket támogató programokat is gondoznak, egy érdekes tendenciát jeleztek. Annak ellenére, hogy szegény, gyakran írástudatlan és alig dolgozó embereket vezetnek, az SHG-kat sokkal jobban menedzselik és irányítják, mint a formális (pl. SACCO vagy NDMFI) szervezeteket. Ezen túlmenően nagyon korlátozott müködési költségekkel, minimális kockázattal járnak az nemteljesítés szempontjából, és az összegyüjtött összegeket és a felhalmozott pénzeszközöket minden tag számára transzparens módon osztják ki a rendszeresen tartott üléseken. Mint ilyen, minden tag „őrző”, mivel megtakarításaikról van szó, így az ellenőrzés szoros és részvételük az SHG vezetésében evidens. Noha hosszú ideje nem volt szabályozási felügyeletük, kevés és kivételesen ritka eset fordul elő, hogy a források elvesznek, és nem okoznak jelentős müködési veszteségeket sem, mivel szinte nincs is müködési költségük. A tapasztalatok szerint (Mutesasira et al 1999) azonban az SHG-k makulátlan és átlátható jellege szétesik, ha külső finanszírozás (akár kormánytól, akár bármely fejlesztési partnertől) áramlik be a szervezetbe. Ebben az esetben az SHG-tagok elsődleges érdeke a megtakarítások védelméröl áthelyeződik a „szabad” pénzeszközök megszerzésére.

2014 végén a becslések szerint 135000 csoport létezett 27 afrikai országban, körülbelül hárommillió taggal, és tagonként átlagosan 30 USD megtakarítással. ${ }^{14}$ Általában 15-30 tagból állnak és nők a tagjai ${ }^{15}$, akik rendszeresen találkoznak. 


\begin{tabular}{|c|c|c|c|c|}
\hline Jellemzők & NDMFI & SACCO & CMFI & SHG \\
\hline $\begin{array}{l}\text { Fókusz és lefed- } \\
\text { ettség }\end{array}$ & $\begin{array}{l}\text { Az ország összes } \\
\text { régiójában jelen }\end{array}$ & $\begin{array}{l}\text { Minden járásban } \\
2-5\end{array}$ & \begin{tabular}{|l|} 
Segélysze- \\
rvezetek mellett
\end{tabular} & $\begin{array}{l}\text { Országszerte } \\
\text { több, mint } 70.000\end{array}$ \\
\hline Tőke-ellátottság & $\begin{array}{l}\text { Jó tőke- } \\
\text { ellátottság, az } \\
\text { adományok } \\
\text { és a pozitív } \\
\text { gazdálkodási } \\
\text { eredmények } \\
\text { miatt } \\
\end{array}$ & $\begin{array}{l}\text { Változó; néhány } \\
\text { esetében nagyon jó, } \\
\text { kb. 1/3-uk esetében } \\
\text { mérsékelt, a többség } \\
\text { alultőkésített }\end{array}$ & $\begin{array}{l}\text { Az üzlet jel- } \\
\text { legéhez képest } \\
\text { nagyon jó }\end{array}$ & $\begin{array}{l}\text { Általában nincs } \\
\text { tőke. Azt helye- } \\
\text { zik ki, hitelezik, } \\
\text { amit betétként } \\
\text { begyüjtenek. }\end{array}$ \\
\hline $\begin{array}{l}\text { Betétek } \\
\text { gyüjtése }\end{array}$ & $\mathrm{n} / \mathrm{a}$ & $\begin{array}{l}\text { Néhány esetében } \\
\text { több mrd. UGX, a } \\
\text { közepes méretűek } \\
\text { esetében néhány } \\
\text { százmillió UGX, a } \\
\text { többség esetében } 50 \\
\text { M alatti } \\
\end{array}$ & $\mathrm{n} / \mathrm{a}$ & $\begin{array}{l}1 \text { és } 10 \text { M UGX } \\
\text { között változik, } \\
\text { minden évben új } \\
\text { ciklus kezdődik }\end{array}$ \\
\hline Hitelek összegei & $\begin{array}{l}\text { Nincs korlátozva. } \\
\text { Általában max. } 5 \\
\text { M UGX minden } \\
\text { csoporttag eseté- } \\
\text { ben (csoportos } \\
\text { hitel); magán- } \\
\text { személy: 100M } \\
\text { UGX }\end{array}$ & $\begin{array}{l}\text { Nincs korlátozva. } \\
\text { Dolgozói körben } \\
\text { szervezett SACCO-k } \\
\text { esetében magasabb: } \\
\text { 50-100 M UGX; } \\
\text { vidéki SACCO-k: } \\
\text { 1-30 M UGX }\end{array}$ & $\begin{array}{l}\text { Kis összegü } \\
\text { mikrohitelek, } \\
\text { néhány százezer } \\
\text { és } 10 \text { M UGX } \\
\text { között }\end{array}$ & $\begin{array}{l}\text { Nagyon kis } \\
\text { összegü hitelek, } \\
\text { általában } 1 \text { millió } \\
\text { UGX alatt és } \\
\text { csak kivételesen } \\
\text { lehet magasabb }\end{array}$ \\
\hline $\begin{array}{l}\text { Finanszírozott } \\
\text { szektorok }\end{array}$ & $\begin{array}{l}\text { Kereskedelem, } \\
\text { kisgazdálkodók, } \\
\text { élelm. feldolg., } \\
\text { mezőgazdasági } \\
\text { alapanyagterm. } \\
\end{array}$ & $\begin{array}{l}\text { Mezőgazdaság, } \\
\text { élelm. feldolg., } \\
\text { kézmüvesek, } \\
\text { szolgáltatások, } \\
\text { kereskedelem } \\
\end{array}$ & $\begin{array}{l}\text { keresk- } \\
\text { edelem, mg. } \\
\text { kistermelők, } \\
\text { szolgáltatási } \\
\text { szektor } \\
\end{array}$ & $\begin{array}{l}\text { kis volumenü } \\
\text { kereskedelem } \\
\text { (piacozás), } \\
\text { esetlegesen mg. } \\
\text { term. és feldolg. }\end{array}$ \\
\hline $\begin{array}{l}\text { Mezőgazdasági } \\
\text { finanszírozás }\end{array}$ & $\begin{array}{l}\text { Szerény mér- } \\
\text { tékben, aránya } \\
\text { általában } 20 \% \\
\text { alatti } \\
\end{array}$ & \begin{tabular}{|l|} 
Jelentős, föleg a \\
vidéki SACCO-k \\
esetében; \\
aránya $70 \%$ fölötti \\
\end{tabular} & $30-50 \%$ & $\begin{array}{l}\text { A városiak: n/a; } \\
\text { a vidékiek } \\
\text { esetében jelentős } \\
(60 \%)\end{array}$ \\
\hline $\begin{array}{l}\text { Ügyfelek/ } \\
\text { fel-használók } \\
\text { száma }\end{array}$ & $500-5,000$ & $\begin{array}{l}\text { Vidéki SACCO: } 200 \\
\text { - 10,000; } \\
\text { Dolgozók által } \\
\text { alapított SACCO: } \\
>50,000\end{array}$ & $100-2,000$ & $15-30, \max .50$ \\
\hline
\end{tabular}

3. táblázat: Az ugandai pénzügyi rendszer 4. szintjének mikrofinanszírozással foglalkozó szervezetei.

NDMFI: Non Deposit Taking Microfinance Institutions - betéteket nem gyüjtö mikrofinanszírozási szervezet; SACCO: Savings and Credit Cooperative Organization - takarék- és hitelszövetkezeti szervezet CMFI: Community Microfinance Institution - közösségi mikrofinanszírozási szervezet; SHG: Self-help Groups - önsegélyezö csoportok

Forrás: EPRC, 2019

Vasa László - Vida Imre: Az önszerveződő csoportok szerepe... 
Az összegyüjtött megtakarítások a csoporttagoknak nyújtott hitelek alapját képezi. A hitelezési ciklusok rögzítettetek (1-3-6- 9-12 hónap), A megtakarításokat és a hitelekből származó hozamot évente elszámolják és szétosztják a tagok között, majd új ciklus kezdődik. A megtakarításokat egyszerü, erős dobozban (safe box vagy strong box) tartják, gyakran három zárszerkezettel ellátva, melyhez három megbízott tagnak van kulcsa. Olyan esetekben, ahol a tagok számolási képessége gyenge, nem használnak feljegyzéseket. Az SHG-k számos előnye azonosítható (Karlan, 2014): 1) A tagok bizalma és vezetésben való részvétele erősödik a gyakori és transzparens elszámolások miatt; minden tranzakcióra minden tag rálát. 2) Nem vesznek igénybe külső tőkét, a fizetett kamat a közösségben marad, a csoportok szervezésének költsége szerény vagy nincs. 3) A rendszeres megtakarítási elkötelezettség ösztönözheti a pénzügyi tudatosságot és megelőzi a szükségtelen kiadásokat. Néhány SHG szintet lép és a hosszabb távra tervező és némileg eltérő elvek mentén müködő ASCA-vá alakul. Ehhez szükséges a papír alapú könyvelés bevezetése.

Élénk vita folyik arról, hogy ösztönözni, erősíteni kell-e a kapcsolatokat az önsegélyező csoportok és a hivatalos FSP-k között. Mind az SHG-k, mind az FSP-k mellett számos előny szól (Bankable Frontier Associates, 2014a, 2014b). Mások azonban óvatoságra intenek, mert az ilyen kapcsolatok alááshatják a tagok erős megtakarítási hajlandóságát, és csökkenthetik a nettó megtakarítással rendelkező tagok számára vonzó kamatbevételeket (Allen, 2010). A csoporttagok közötti kapcsolatok sérülhetnek, ha az FSP-k megkövetelik, hogy a csoportos megtakarításokat használják fel az egyedi, nagyobb összegű hitelek kihelyezéséhez. A Banking on Change ${ }^{16}$ partnerkapcsolatain keresztül a Barclays Bank, a CARE International UK és a Plan UK azon dolgozik, hogy az SHG-ket hivatalos banki szolgáltatásokhoz kapcsolják Afrikában (Egyiptom, Ghána, Kenya, Mozambik, Tanzánia, Uganda és Zambia), Ázsiában (India, Indonézia és Vietnám) és Dél-Amerikában (Peru). Az egyedi megoldásokat az egyes országokban fennálló feltételekhez igazítják. Ez a partnerség az első három évében több mint 500000 embert ért el (Allan et al., 2013).

Az ugandai kormányzat felismerte a mezőgazdasági kistermelők pénzügyi rendszerekhez való hozzáférésének problémáit és ennek érdekében - más intézkedések mellett - létrehozta a Mikrofinanszírozási Támogatási Központot (MSC), amely a mikrofinanszírozási intézmények (MFI-k) és szövetkezetek támogatására irányul, amelyek prioritása a mezőgazdasági ágazat finanszírozása. Az MSC üzleti fejlesztési támogatást, valamint hiteleket nyújt a takarék- és hitelszövetkezeti szervezeteknek (SACCO-k), MFI-knek, szövetkezeteknek, falusi megtakarítási- és hitelszövetkezeteknek (VSLA), valamint a kis- és középvállalkozásoknak (Meyer, 2015).

\section{Megtakarítási és hitelszövetkezetek - a SACCO rendszer}

A mikrohitelezéssel foglalkozó közösségi bankoknak már komoly története van a kontinensen. Évtizedek óta léteznek különböző önsegítő csoportok, hitelszövetkezetek, körforgásos alapon müködő hitelintézetek, amelyeknek termékei (illetve sokszor csak egyetlen terméke) a célcsoport igényei alapján jöttek létre (Borbély, 2014). 


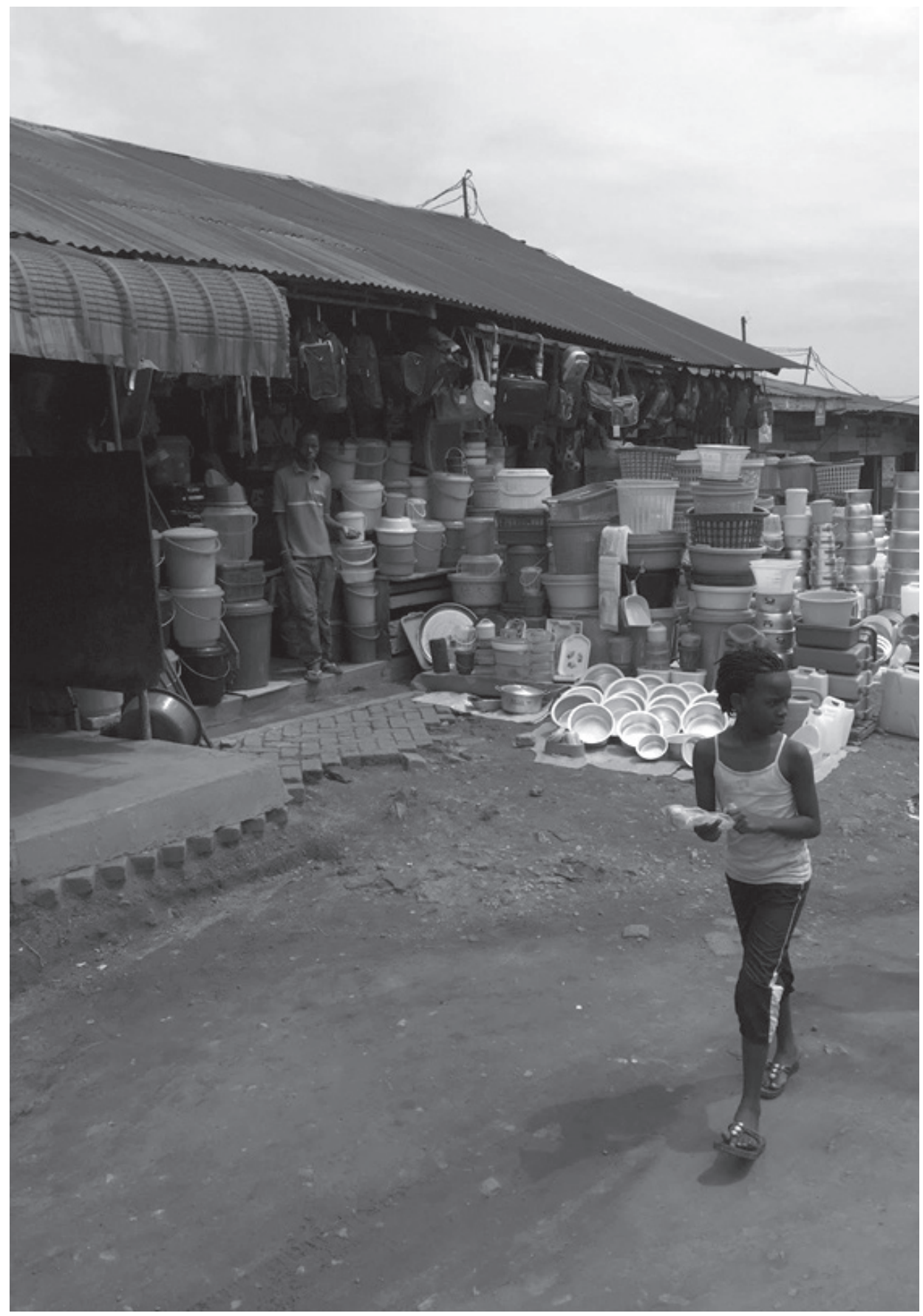

^ Piaciárus Kampalában-saját forrás 
A szövetkezetek Ugandában - a többi kelet-afrikai országokhoz hasonlóan a társadalom és a vidékfejlesztés jelentős pillérévé váltak az elmúlt negyven évben. A szövetkezetek olyan gazdálkodók támogatására alakultak, amelyek részt vesznek készpénznövények, pl. kávé, gyapot és dohány előállításában és forgalmazásában. Számos vidéki szövetkezet kapott támogatást a kormánytól az 1970-es évek során, ám a kereskedelem liberalizációja, az erősödő világpiac és a korrupció a szövetkezeti szektor összeomlását eredményezte. Ugandában csak kevés szövetkezet maradt fenn, sok vidéki gazdálkodó kiábrándult a szövetkezeti mozgalom kudarca miatt. Az újjászervezés majdnem egy évtizedig tartott, miután egyes helyi közösségek megtakarítási és hitelszövetkezeteket (SACCO) alakítottak vidéki és városi térségekben. A szövetkezetek új generációját több intézmény és ügynökség felügyelte és gondozta, ideértve a két ugandai ernyőszervezetet: az Ugandai Szövetkezeti Szövetséget (UCA) és az Ugandai Szövetkezeti Takarékpénztárak Unióját (UCSCU).

A takarék- és a hitelszövetkezetek (SACCO) szövetkezeti törvényi alapon működő, tagi (azaz az ügyfelek) tulajdonú és irányítású szervezetek Kelet-Afrikában (elsősorban Ugandában, Tanzániában és Kenyában), tagjaik létszáma néhány tucattól a több ezerig terjed. A legtöbb SACCO egy adott cég munkavállalóin alapul, mások a termelői piacok köré szerveződnek és vannak, amelyek egy adott termék termelöit (leginkább a kávétermelöket) foglalják magukba. A SACCO-k több ok miatt is alkalmasak arra, hogy mikro-megtakarítási és -hitelezési szolgáltatást nyújtsanak a szegényebb rétegeknek, különösen a vidéki területeken.

A SACCO-kat a Kereskedelmi, Ipari és Szövetkezeti Minisztérium (Ministry of Trade, Industry and Cooperatives, MTIC) nyilvántartásba veszi, és a müködési jellemzőik alapján Ugandai Mikrofinanszírozást Szabályozó Hatóság (Uganda Microfinance Regulatory Authority, UMRA) vagy a minisztérium (MTIC) szabályozza. A vidéki SACCO-k (falusi) közösségi alapúak, míg a legtöbb városi és agglomerációs munkavállalói kollektíva vagy foglalkozás alapúak. A SACCO-kat alapjában véve szövetkezeti törvények és alapelvek szabályozzák.

Mindaddig, amíg tagjaikkal - akik tulajdonosok is egyben - folytatnak üzleti tevékenységet, müködési területük elvileg korlátlan. De a gyakorlatban müködésük területi kiterjesztését egyébként is erőteljesen korlátozza az a képesség, hogy egy meghatározott földrajzi területeken kívül képesek-e szolgáltatást nyújtani. Egy tipikus, jól működő SACCO megtakarítási portfóliója két-háromszorosa a kihelyezett hitelportfóliójának. Azon szövetkezetek, amelyek esetében a hitelállomány messze meghaladja a megtakarítási betétek volumenét, általában müködési problémával küzdenek. A megtakarítási és hitelportfóliók jelentősen különbségeket mutatnak, a legalacsonyabb 10 millió UGX-től (2 631 USD) az 5 milliárd (1,315 M USD) vagy több UGX állományig.

Az szövetkezeti alapelveknek megfelelöen a SACCO-k üzletvitelét és -politikáját nagyrészt az éves közgyülések (Annual General Meetings, AGM) tagsága határozza meg, ezeket a SACCO bizottság vagy az igazgatóság hajtja végre, amelyek általában a SACCO legfelsőbb irányító szervei. Minden SACCO-nak van audit és felügyelő bizottsága, amelyek közösen felügyelik a menedzsmentet és jelentést tesznek a 
közgyülésnek. Az UMRA engedélyezési kritériumok alapján minősített SACCOkat az UMRA szabályozza, és azokat is, amelyeket a minisztérium nem. Régóta elégedetlenség tárgya volt a SACCO-k felügyeletének és szabályozásának módja és végrehajtása, amely jelentős rész a szövetkezeti rendszer fentebb említett, '80-as és '90-es években történt összeomlásának eredménye. Ebből a szövetkezeti szektornak a mai napig nem sikerült felépülnie.

A SACCO-k a vidéki térségekben gyakoriak, és azok, amelyek tagsági alapon, minden külső finanszírozási ígéret nélkül (ön)szerveződtek, ellenállóképesebbnek bizonyultak azoknál, amelyek létrehozását a kormány vagy annak fejlesztési partnerei kezdeményeztek és külső alapok igénybevételére alakultak. Ez utóbbiak vagy már megszüntek, vagy súlyosan meggyengültek (lásd a Sacco-k és a politika kapcsolatát a cikk további részében). A hitelnyújtási oldalon a SACCO-k ágazati vagy célspecifikus termékeket fejlesztettek ki - például mezőgazdasági, iskolai díjakat fedező kölcsönöket.

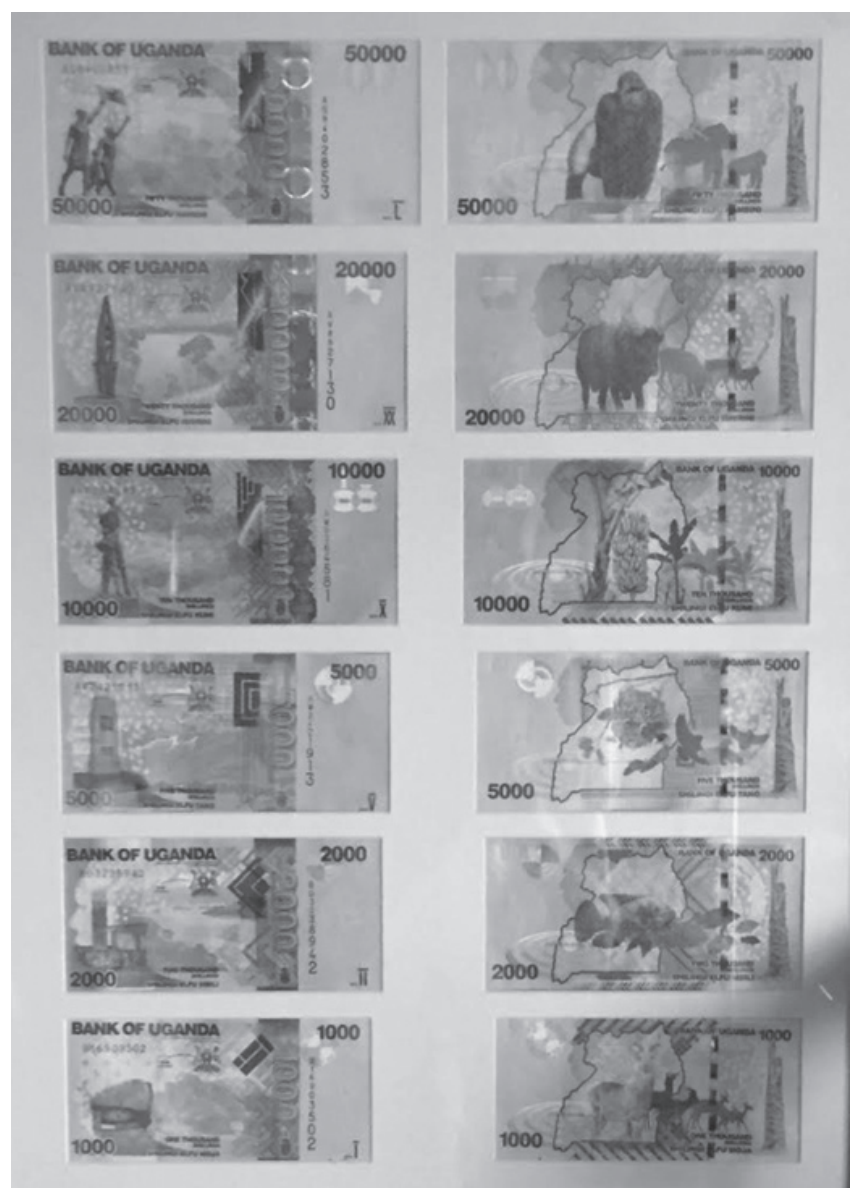

^Az ugandai shilling-saját forrás 
A SACCO-k technikai támogatást kapnak az UCA-tól vagy az Ugandai Szövetkezeti Takarékpénztárak Uniójától (Uganda Cooperative Savings and Credit Union, UCSCU $)^{17}$. Az ügyfelek többsége nettó hitelfelvevő, mindössze $10 \%$-uk nettó megtakarító. A tagok körében a SACCO-k népszerüek, mivel a bankokhoz képest egyszerü és olcsó kölcsönök forrásai, elérhetők és gyakran a tagok munkahelyeinek és otthonának közelében helyezkednek el, napi betéti beszedési szolgáltatásokat, és gyors rövid távú kölcsönöket nyújtanak, amelyek felhasználhatók a háztartási likviditási gondok megoldására és lehetővé teszik egyes fogyasztási igények kielégítését. Jogi szempontból a SACCO-k jelentős előnye, hogy jogosultak megtakarításokat kezelni, és azokat hitelezési célokra felhasználni (Mutesasira et al 1999).

\section{Az ugandai SACCO-k problémái}

Mint a fejlödő világ legtöbb országában, az ugandai SACCO-k is számos olyan problémával szembesültek, amelyek negatívan hatottak pénzügyi szolgáltatóként való megítélésükre. Hagyományosan átláthatatlan a menedzsment és hiányoznak az egyszerủ és átlátható szabályok. A tagi/tulajdonosi státusz és az irányítás szétválasztása gyakran nem müködik, egyes elnökök az intézmény tulajdonosának tekintik magukat. A tagság intézmény ügyeibe való bevonásának elmaradása lehetőséget teremt az igazgatóságnak, az operatív vezetésnek és kapcsolati körüknek, hogy hitelt vegyenek fel az adott SACCOtól anélkül, hogy teljesítenék visszafizetési kötelezettségüket. A számviteli rendszerek általában bonyolultabbak a kelleténél, gyakran csak alacsony kapacitással és nem jó struktúrában működnek. Az ellenőrzések ritkák és hiányosak. Ezen túlmenően, mivel a SACCO tagok többsége általában nettó hitelfelvevő, igyekszik minimalizálni a kölcsönök kamatlábait - ami nem ösztönzi a megtakarítást, és eredményez elegendő bevételt a szervezet müködtetéséhez. A SACCO-k gyakran hiteleznek tőkéjük és a megtakarítások terhére is, ami gyakran okoz likviditási problémákat. A hitelezési szabályokat általában nem tartják be, és a hátralékok nyomon követésére és kezelésére szolgáló rendszerek alig léteznek. Ennek eredményeként az legtöbb ugandai SACCO jelentős rosszul teljesítő portfólióval rendelkezik, a késedelmes kölcsön-visszafizetés, illetve azok teljes elmaradása igen gyakori (Mutesasira et al 1999).

A SACCO-k a vidéki
térségekben gyakori-
ak, és azok, amelyek
tagsági alapon, min-
den külsó finanszí-
rozási ígéret nélkül
(ön)szervezódtek,
ellenállóképesebbnek
bizonyultak azoknál,
amelyek létrehozását
a kormány vagy an-
nak fejlesztési partne-
rei kezdeményeztek
és külső alapolk igény-
bevételére alakultak.
Ez utóbbiak vagy már
megszúntek, vagy
súlyosan meggyen-
gültek.


A SACCO-k számára jelentős nehézségeket okoz a hitelfedezetek likvidálása, végrehajtása. Közösségi alapú, tagi tulajdonban lévő és tagok által menedzselt szervezetek lévén, a végrehajtással megbízott tisztviselők vonakodnak - adott esetben akár rokonaikhoz vagy szomszédjaikhoz tartozó - vagyontárgyak lefoglalásától és eladásától (Dichter 1997; Wright, 1999). Az ugandai mikrofinanszírozási közösség legtöbb kulcsszereplöje úgy véli, hogy a SACCO-k és más közösségi alapú szervezetek elméletileg képesek hozzájárulni a szegényeknek nyújtott pénzügyi szolgáltatások bővítéséhez, különösen a vidéki területeken. A mai napig tapasztalt nem kielégítő teljesítményük és az ezzel járó irányítási problémák miatt a legtöbb érdekelt- köztük több kormányzati tisztviselő is- óvatos a közösségi alapú szervezetek (communitybased organizations, CBO) jövöjével kapcsolatban. Egy nagy mikrofinanszírozási szolgáltató egyik ügyvezetöje kijelentette, hogy a demokrácia rendben van a szavazóhelyiségben, de a pénzügyi intézményekben nem müködhet jól.

Mind az Ugandai Szövetkezetek Szövetsége (UCA), mind az Ugandai Szövetkezeti Takarékpénztárak Uniója (UCSCU) gyengének tekinthető, maguk is módszertani és kapacitásépítési problémákkal küzdenek (Wright, 1999). Az UCA azonban új és potenciálisan sikeres megközelítés mentén indult el és úgy tünik, hogy egyre növekvő számú SACCO müködik kielégítően. Általánosságban úgy tünik, újra erősödik az érdeklődés a közösségi alapú megtakarítási és hitelintézetek iránt. A már lezárult, Afrikai Fejlesztési Bank által támogatott, vidéki mikrofinanszírozás ösztönzési programnak (Rural Microfinance Support Project, RMSP) ${ }^{18}$, a dán kormányzati DANIDA ${ }^{19}$ program vidéki finanszírozást érintő kapacitásépítő komponense (Rural Financial Services Component, RFSC) ${ }^{20}$ vagy a svájci Swisscontact szervezet idén befejeződött Inclusive Finance Programja (IFP) ${ }^{21}$ jelentősen növelte közösségi alapú szervezetek elfogadottságát és presztízsét. A Hitelszövetkezetek Világuniója (World Council of Credit Unions, WOCCU) 2000 óta van jelen Ugandában, a USAID támogatásával, fó célja a SACCO-kkal való együttmüködés. A WOCCU-val együttmüködésbe belépő SACCO-knak transzparenssé kell tenniük müködésüket és gazdálkodásukat a WOCCU számára, és kötelezettséget kell vállalniuk egy átfogó szerkezetátalakításra.

Más közösségi alapú szervezetek, például a pénzügyi szolgáltatási szövetségek (Financial Service Association, FSA) hasonló problémákkal szembesültek, mint például a SACCO-k. Eltérő intézményi felépítésük és irányítási struktúrájuk, valamint a technikai segítség igénybevétele miatt azonban egyes FSA-k rendkívül jól teljesítettek annak ellenére, hogy nehéz vidéki környezetben müködnek. Az üzletre jobban fókuszáló megközelítésük komparatív előnyt biztosít számukra a SACCO-kkal szemben, és így potenciálisan alkalmasak pénzügyi szolgáltatások nyújtására olyan ügyfelek számára olyan területeken, amelyeket a hagyományos MFI-k általában nem szolgálnak ki. A legfrissebb, 2015-ös cenzus eredményei azt mutatták, hogy a meglévő SACCO-k 45\%-a nem müködött, vagy müködésük szünetelt. A vidéki szegények mikrofinanszírozáshoz való hozzáférése így szűkül. A leginkább a keleti és az északi régiókat érintette (4. táblázat). Ennek több oka is van, melyet az alábbiakban részletezünk. 


\section{A politika és a SACCO-k}

A mezőgazdasági jövedelmek növelése volt az Uganda Párt 2006. évi választási programjának középpontjában és ennek érdekében kidolgozták a „Jólétet mindenkinek” (,Bona Bagaggawale” Prosperity for All, PFA) programot (Afranaakwapong et al, 2015). Az ugandai kormány ezzel a programmal helyezte át a vidéki hitelezési rendszer fókuszát a megtakarítási és hitelszövetkezeti (SACCO) szektorra. Ezeket az SACCO-kat azért hozták létre, hogy helyettesítsék, kiváltsák az politikai elit által ellenőrizhetetlen és nem befolyásolható, klasszikus mikrofinanszírozási szervezeteket. A jól bevált mikrofinanszírozással (amelyet a kormány az 1990-es évek végén és a 2000-es évek közepén támogatott és finanszírozott) ellentétben a politikailag befolyásolható SACCO-kat hatékony eszköznek tekintették Uganda közepes jövedelmü országgá válásához. Ennélfogva a PFA-program keretében nemcsak arra számítottak, hogy a SACCO-k helyettesíthetik a mikrofinanszírozást, hanem úgy tekintették, hogy ez az összes ugandai szegény számára jólétet biztosít.

Ellentétben a tagok tulajdonában lévő hagyományos SACCO-kkal, amelyek tagmegtakarításokra és részvénytőkere támaszkodnak, a politikai SACCO-k szinte teljes egészében a mikrofinanszírozási támogató központ (MSC) és az Uganda Posta által közvetített állami hitelekre támaszkodtak.

A politikai SACCO-k számára a kormány nem csak azt engedélyezi, hogy tagjainak megtakarításait vagy betéteit elfogadja anélkül, hogy az Ugandai Központi Bank engedélyt kellene beszereznie, hanem a piaci kamatlábak alatti kihelyezhető állami forrást is kaphat, hogy a tagoknak olcsó hitelként szétosszák. Cserébe a politikai elit az állami hiteleket használja fel eszközként az ilyen SACCO-k és a vidéki térségek politikai folyamatának ellenőrzése és befolyásolása érdekében. A Bona Bagaggawale a szegénység csökkentéséből a szerkezeti átalakuláshoz és a gazdasági fejlődéshez való elmozdulást jelezte: kölcsönöket folyósítottak azoknak, akik segítették a kormány érdekeit, tehát a rendszer átpolitizálttá vált. (Makoba et al, 2015)

A Nemzeti Mezőgazdasági Tanácsadási Szolgáltatások program (National Agriculture Advisory Services, NADS) 2007 évi első felülvizsgálata után, a kormány mikrofinanszírozási támogatási központokat (Microfinance Support Center, MSC) hozott létre országszerte. Ez a politikailag befolyásolt SACCO-k létrehozásának

\begin{tabular}{l|c|c|c|c|c}
\hline Kategória & Közép-UG & Ny-UG & K-UG & É-UG & Összesen \\
\hline Aktív, validált adatokkal & 156 & 318 & 154 & 79 & 707 \\
\hline Aktív, nem validált adatokkal & 50 & 110 & 159 & 73 & 492 \\
\hline Szünetel & 48 & 38 & 102 & 68 & 256 \\
\hline Megszűnt & 41 & 112 & 253 & 236 & 642 \\
\hline Összesen & 295 & 578 & 668 & 456 & 1.997 \\
\hline
\end{tabular}

\4. táblázat: A SACCO-k müködési státusza a 2015-ös cenzus alapján.

Forrás: Ministry of Finance, Planning and Economic Development, 2015 MFI Census 
részét képezte. Ezek nem tévesztendők össze az ugyanígy nevezett hagyományos, önszerveződésen alapuló takarék- és hitelszövetkezetekkel), amelyek „,szinte teljes egészében az állam által biztosított hitelekre támaszkodtak a mikrofinanszírozási támogató központok (MSC) és az Uganda Post Bank révén" (Makoba \& WakokoStudstill, 2015). Az MFC pénzügyi tanácsadói a gazdálkodói csoportok integrált támogatási rendszere (Integrated Support to Farmer Groups, ISFG) keretében járási szinten vettek részt a gazdálkodók pénzügyi képzésében. Mindemellett a hagyományos elvek szerint, alulról (ön)szerveződő takarék- és hitelszövetkezeti szervezeteket (SACCO), a Centenary Rural and Development Bankot ${ }^{22}$ (CERUDEB) és más nem kormányzati szervezeteket a kormány által irányított MSC körbe kerültek, az olcsó finanszírozásnak köszönhetően (ROU, 2008b). Az ISFG volt az eszköz, amelyen keresztül a kormány által biztosított olcsó finanszírozást a mezőgazdasági termelők szövetségeihez csatornázták be. Makoba et al. (2015) feltárták azokat a kihívásokat, amelyekkel a legkisebb, szubsztantív termelést folytató gazdák szembesültek, amikor a vidéki hitelforrások egyre inkább állami irányítás alá kerültek a politikailag

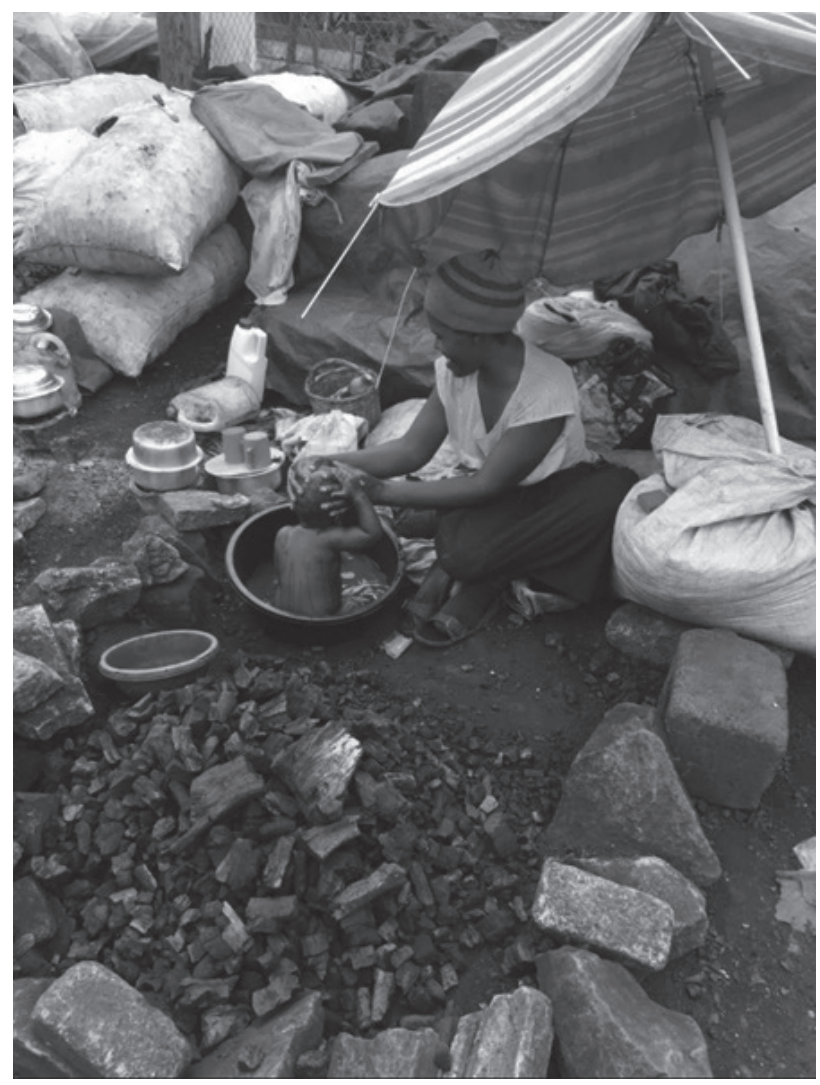

^Édesanya fürdeti a gyermekét miközben a piacon árulja a portékáját- a SACCO-kfö ügyfélkörének mindennapjai - saját forrás 
befolyásolt SACCO-k révén. A vidéki szegények megélhetése alapvetően az eszközök rendelkezésre állásától függ, elsősorban a pénzügyi eszközöktől; a kormány mikrofinanszírozási rendszerének változásai viszont valójában a legszegényebbeket kizárták a rendszerből (Afranakwapong et al, 2015; James, 2010; Makoba et al, 2015; Manji, 2010). A vidéki, túlnyomórészt mikrofinanszírozási alapú hitelforrások politikailag befolyásolt SACCO-kkal történő felváltása óriási kihívásokat jelentett a megélhetési célú gazdálkodók számára: a gyakorlat szerint ugyanis csak a politikai kapcsolatokkal rendelkezők jutottak forrásokhoz. Makoba et AL (2015) összehasonlító elemzése rámutatott, hogy ,a program nem ösztönözte a gazdasági fejlődést és nem csökkentette a krónikus szegénységet, mert tevékenységei és müveletei kizárták azokat a vidéki embereket, akiknek leginkább szükségük van rájuk".

Gyakorlatilag egyetlen, politikai alapon müködő SACCO fölött sincs hivatalos szabályozási felügyelet, és nem függetlenek a politikai beavatkozástól sem. Az UCSCU ernyojje alatt létrehozott hagyományos SACCO-kat ugyanez a szervezet felügyeli. A politikai SACCO-kra azonban nem vonatkozik az 1991. évi szövetkezet törvény, így azok nem tartoznak az UCSCU felügyelete alá. Ennél is fontosabb, hogy a politikai SACCO az egyetlen olyan pénzügyi intézménytípus, amely az Ugandai Központi Bank engedélye és felügyelete nélkül gyüjthet betéteket [36]. Ez tervezett módon alakult így, mivel a politikai célok elérése volt a lényeg. Részben ez az oka annak is, hogy az Európai Bizottság ugandai küldöttsége sürgette a kormányt, hogy fogadjon el olyan jogszabályt, amely rögzíti a SACCO-k jogi státusát és függetlenségét. ${ }^{23}$

A kormány nemcsak a SACCO-k létrehozásának kritériumainak meghatározásában vesz részt, hanem az egyes megyékben 30 részt vevő háztartás kiválasztásában is, valamint a SACCO-k mobilizálásában és indításában is. ${ }^{24}$

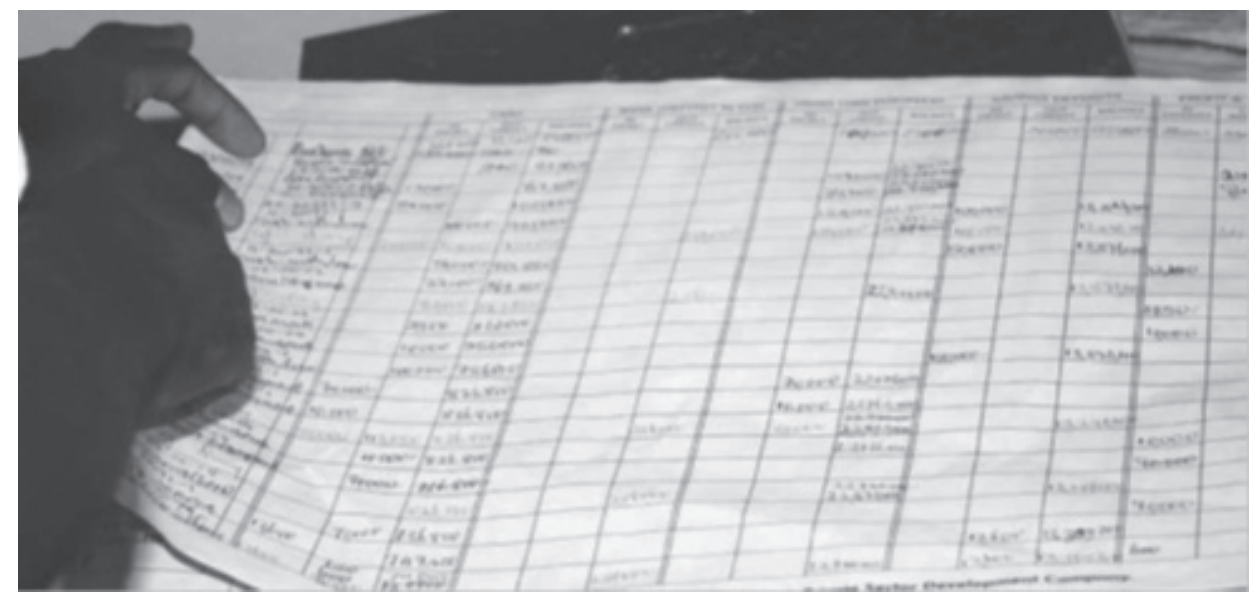

^Forrás: https://www.newvision.co.ug/new_vision/news/1424421/govt-revive-ugandacooperative-bank 


\section{Konklúzió}

Bár a SACCO-kat esetenként átszövi a politika, mégis jelentős szerepük van a szegényebb rétegek felzárkóztatásában. Sokszor csak ez az egyetlen esélye van kitörnie valakinek abból az élethelyzetből, melybe önhibáján kívül, vagy társadalmi helyzetéből fakadóan került. Külső forrást, hitelt, anyagi támogatást szerezni egy olyan élethelyzetben - ahol sokszor a puszta túlélés a cél - nem a legegyszerúbb feladat. Pedig ahhoz, hogy a szegényebb társadalmi rétegek kellő motivációt és előre lépési lehetőséget tudjanak találni, ez a forrásteremtés elengedhetetlen. A megtakarítások ösztönzése emellett nem elhanyagolható, de mindenképp másodlagos szerepet játszik.

A SACCO-k akkor teljesítenek a legjobban, amikor az emberek (külső nyomás nélkül) önszántukból egyesítik erőforrásaikat, hogy pénzügyi szolgáltatásokat nyújtsanak a tagok számára. A legfontosabb pénzügyi termékük az alapvető megtakarítások és a személyi kölcsönök. Ebböl is látszik, hogy ha alapvető hiányoságok is vannak a múködésük terén, és jövőbe mutató változásokra van szükség a szabályozásokban, hosszú távon elengedhetetlenek, mert rengeteg embert érintenek és közvetlen gazdaságélénkítő hatása van ezen szervezetek müködésének.

Sajátos, helyi szerveződések, de talán pont ezért könnyen és gyorsan reagálnak a mikroszintủ piaci igényekre. A földrajzi és a társadalmi szempontokat figyelembe véve kijelenthetjük, hogy: közvetlen elérést biztosítanak azokhoz az emberekhez, akiket más pénzügyi csatornák még csak nem is jegyeznek. Így a legfontosabb feladatukat, vagyis a társadalmi felzárkóztatást és a szegényebb rétegek leszakadásának lassítását mindenképpen ellátják.

\section{Jegyzetek}

1 A Grameen Bankot (a bengáli gram szó falut jelent) 1983-ban alapította meg Muhammad Yunus bangladesi közgazdász professzor. Az alapító a „szegények bankja” koncepcióért megkapta a 2006. évi Nobel-békedíjat.

2 Bank of Uganda: „Supervision: Supervised Financial Institutions” https://www.bou.or.ug/ bou/supervision/financial_institutions.html

$31 \mathrm{USD}=3.788$ ugandai shilling (UGX) (2020.05.20.)

4 https://data.imf.org/?sk=E5DCAB7E-A5CA-4892-A6EA-598B5463A34C

$5 \mathrm{FSD}=$ Financial Sector Deepening Uganda

6 burial/Engozi societies - egyfajta önszerveződő temetkezési biztosítási közösség, a tagok havonta kis összeget fizetnek egy közösség alapjába, temetkezésük „előfinanszírozásaként”; ezek a szervezetek lettek később a hasonló alapon szerveződő falusi egészségpénztárak alapjai - lásd Jones, 2009; Halvorson, 2007

7 https://datacatalog.worldbank.org/dataset/uganda-global-financial-inclusion-global-findexdatabase-2017 adatbázis

8 https://www.cgap.org/

9 A MIX Market az afrikai mikrofinanszírozási intézmények adatszolgáltató és -kezelő platformja https://www.themix.org/mix-market

10 Az ROSCA-k általában autonóm módon kialakult, több tagból álló csoportok, amelyek rendszeresen találkoznak, hogy megtakarításokat gyüjtsenek és az összegyült pénzt folyósítják egy tagnak. Addig folytatják, amíg minden tag meg nem kapja a bankot. Az ASCA hasonló, azzal a különbséggel, hogy megtakarításokat lehet felhalmozni és kölcsönözni a tagok és a nem tagok számára. 
11 Az FSA-kat a társasági törvény szerint részvénytársaságokként tartják nyilván, kifejezetten nyereségorientált vállalkozásként működnek. Az osztalék általában magasabb, mint a szövetkezetek esetében az eltérö üzleti orientációjuk miatt. A szövetkezetektől eltérően, amelyek egy tag egy szavazat elven müködnek, az FSA-k szavazati joga attól függ, hogy mennyi részvénye van egy elöre meghatározott maximumon belül (gyakran személyenként 10 szavazat). Ez ösztönzi a nagyobb részvényekkel rendelkező egyéneket az irányításban / felügyeletben való aktívabb részvételre. Elsősorban befektetők irányítják, ez tükröződik a hitelfelvevők által fizetett magas kamatokban és a betéteseknek kínált nulla értékű hozamban.

12 A Tier 4-be tartozó intézményeket nem szabályozza az ugandai közpinti bank (Bank of Uganda). Tagjaikon kívül nem jogosultak betéteket elfogadni, biztosítékkal vagy biztosíték nélkül is nyújthatnak viszont kölcsönöket a nyilvánosság számára. Több ezer ilyen intézmény létezik az országban. https://ulii.org/ug/legislation/act/2016/4

13 https://www.ilo.org/wcmsp5/groups/public/---ed_emp/---emp_ent/---coop/documents/ publication/wcms_672969.pdf

14 Csak a nemzetközi segélyszervezetek által támogatott projektekre vonatkozik. Lásd https:// www.researchgate.net/publication/333238735_Global_Indicators_of_Savings_Groups

15 Lásd: and Nino-Zarazua (2011)

$16 \mathrm{https}: /$ www.careevaluations.org/wp-content/uploads/evaluations/4-final-report-banking-onchange-phase-2-feb-2016.pdf

17 https://ucscu.coop/

18 https://projectsportal.afdb.org/dataportal/VProject/show/P-UG-IE0-002

19 Danish International Development Agency https://um.dk/en/danida-en/

20 https://www.bis.org/review/r161020b.pdf

21 Swiss Foundation for Technical Cooperation, svájci segély- és nemzetközi fejlesztési szervezet https://www.swisscontact.org/fileadmin/user_upload/COUNTRIES/Kenya/Documents/ Publications/IFP_MFIs_and_SACCOs_Factsheet_-_Kenya.pdf

22 A bank az egyik legnagyobb pénzintézet Ugandában, elsősorban a vidéki gazdálkodóknak, a mezőgazdasági termékek feldolgozóinak, kiskereskedőknek, manufaktúráknak és külkereskedelemmel foglalkozóknak nyújt jellemzően fejlesztési hitelt. Klasszikus kereskedelmi banki tevékenységet folytat, de portfóliójának jelentős része a mikrofinanszírozási területhez kapcsolódik. 2018 decemberében a bank eszközei 862 millió USD értékűek voltak. Részvényeinek 70\%-a két római katolikus rend tulajdonában van. https://www.centenarybank.co.ug/ index.php/about-us

23 Melissa Duscha, 2008, https://www.microcapital.org/microcapital-story-ugandangovernment-to-set-up-laws-for-regulating-its-microfinance-sector/

24 lásd Makoba, 2011

\section{Felhasznált irodalom}

- Afranakwapong, N., - Nkonya, E. (2015): Agricultural extension reforms and development in Uganda. Journal of Agricultural Extension and Rural Development, 7(4), 122-134.

- Allen, H (2010): Why I think that community-managed microfinance programmes should be careful about borrowing from banks. In: Wilson, K et al. (eds). Financial Promise for the Poor: How Groups Build Microsavings. Kumarian Press. http://savings-revolution.org/doclib

- Allan, A et al. (2013): Banking on change: breaking barriers to financial inclusion. Banking on Change Partnership, London. www.microfinancegateway.org/sites/default/files/mfg-encase-study-bankingon-change-breaking-barriers-to-financial-inclusionjan-2013.pdf

- Anderson, J. - C.E. Learch - S.T. Gardner (2016): National Survey and Segmentation of Smallholder Households in Uganda: Understanding Their Demand for Financial, Agricultural, and Digital Solutions. CGAP Working Paper Washington, DC 
- BoU (Bank of Uganda) (2017): Annual Supervision Report. Issue No. 8. December. https:// www.bou.or.ug/bou/bou-downloads/asr/2017/Dec/Annual-Supervision-Report-2017.pdf

- Bankable Frontier Associates (2014a): Focus Note 1: Outcompeting the Lockbox — Linking Savings Groups to the Formal Financial Sector. Somerville, MA. http://bankablefrontier.com/ wp-content/uploads/documents/BFA-Savings-Group-Linkages-Focus-Note-1.pdf

- Bankable Frontier Associates (2014b): Focus Note 2: SG Linkages - The Business case for Private Service Providers. Somerville http://bankablefrontier.com/wp-content/uploads/ documents/BFA-Savings-Group-Linkages-Focus-Note-2.pdf

- Borbély, E. (2014): Etikus finanszírozás a szubszaharai Afrikában. Afrika Tanulmányok, VI (1)

- C. Churchill, \& C. Frankiewicz, (2006): "Making Microfinance work: Managing for Improved Performance", The International Training Centre of the ILO in Turin, Italy.

- Demirgüç-Kunt, A. - Klapper, L. - Singer, D. - Ansar, S. - Hess, J. (2018): The Global Findex Database 2017: Measuring Financial Inclusion and the Fintech Revolution. Washington, DC: World Bank https://openknowledge.worldbank.org/handle/10986/29510

- Dichter, T. W. (1998): „Evaluation of FINCA/Uganda and PRIDE Africa Uganda“, The Austrian Regional Bureau for Development Co-operation

- EPRC (Economic Policy Research Centre) (2019): Agricultural Finance Year Book 2019 - Development Financing for Agro-industrialisation. https://eprcug.org/research/ education/592-agriculture-finance-year-book-2019-development-financing-for-agroindustrialisation

- FSD Uganda (2018): FinScope Uganda 2018. https://fsduganda.or.ug/wp-content/ uploads/2018/10/FinScope-Uganda-Survey-Report-2018.pdf

- Imreh, Sz. - Kosztopulosz, A. - Mészáros Zs. (2007): Mikrofinanszírozás a legszegényebb rétegeknek: az indiai példa. Hitelintézeti Szemle 6 (3) pp. 231-247.

- James, P. A. S. (2010): Using farmers' preferences to assess development policy: A case study of Uganda. Development Policy Review, 28(3), 359-378.

- Johnson, S - Nino-Zarazua, M (2011): Financial access and exclusion in Kenya and Uganda. The Journal of Development Studies 47(3) 475-496. http://opus.bath.ac.uk/20008/1/Johnson_ JDV_2011_47_3_475.pdf

- Karlan, D (2014): The next stage of financial inclusion. Stanford Social Innovation Review Fall 2014 42-49. www.ssireview.org/pdf/Fall_2014_The_Next_Stage_of_Financial_Inclusion_1. pdf

- Ledgerwood, J. (1999): Microfinance Handbook. World Bank, Washington

- Makoba, J.W. (2011): Rethinking development strategies in Africa : the triple partnership as an alternative approach : the case of Uganda. Africa Development Series V. Peter Lang Publishing, Bern

- Makoba, J.,W., - Wakoko-Studstill, F. (2015): From prosperity for all (PFA) to prosperity for few (PFF): Political SACCOS and their impact on rural development in Uganda. Journal of Third World Studies, 32(2), 99-122.

- Mallinguh, E. - Zéman, Z (2018): Domestic Credit to the Private Sector by Banks within East Africa Economic Block. Economics \& Working Capital 2018 (3-4) pp. 7-13.

- Manji, A. (2010): Eliminating poverty? Financial inclusion, access to land, and gender equality in international development. Modern Law Review, 73(6), 985-1004.

- Meyer R. L. (2015): Financing Agriculture and Rural Areas in Sub-Saharan Africa: Progress, challenges and the way forward. IIED Working Paper. IIED, London.

- Ministry of Finance, Planning and Economic Development (2016): BMAU Briefing Paper 15/16 https://www.finance.go.ug/sites/default/files/Publications/BMAU\%20Briefing\%20 Paper\%2015-16\%20-\%20Improving\%20access \%20to\%20rural\%20microfinance. $\% 20$ What $\% 20$ must $\% 20$ be $\% 20$ done.pdf 
- Mutesasira, L. - Sempangi, H. - Hulme, D. - Rutherford, S. - Wright, G. A. N. (1999): „Use and Impact of Savings Services among the Poor in Uganda"MicroSave http://www.microsave. net/files/pdf/Use_and_Impact_of_Savings_Services_Among_the_Poor_in_Uganda.pdf

- Neszmélyi, Gy. (2016): Örségváltás Afrika óriásánál Nigéria gazdasági és társadalmi kihívásai. In: Vágány, Judit; Fenyvesi, Éva (szerk.) Multidiszciplináris kihívások, sokszínű válaszok. Budapest, Magyarország: BGE KVIK Közgazdasági Intézeti Tanszéki Osztály, (2016) pp. 130-146.,

- Oláh, J. - Molnár, T. (2001): A Mikrohitel Program bemutatása, folyósításának rendszere és tapasztalata. Agrártudományi Közlemények / Acta Agraria Debreceniensis Különszám pp. $81-86$

- Oshora, B. - Magda, R. (2019): Contribution of micro and small enterprises for youth unemployment: ethiopia experience. In: Rusko, M.; Klinec, I. - K., Nemoga (szerk.) Proceedings of the 9th International Scientific Conference, Zilina, Slovakia. Edis Publishing Institution of the University of Zilina pp. 75-85.

- Popp, J. - Oláh, J. - Kiss, A. - Lakner, Z. (2019): Food security perspectives in Sub-Saharan Africa. Amfiteatru Economic 21 (51) pp. 361-376.

- Republic of Uganda (2017): National Financial Inclusion Strategy 2017-2022. https://www. bou.or.ug/bou/bou-downloads/publications/special_pubs/2017/National-Financial-InclusionStrategy.pdf

- Panturu, C. (2019): Introducing Agency Bankingh in Uganda: A New Channel to Increase Financial Inclusion. United Nations Capital Development Fund.

- Pásztor, Sz. (2019): Monetáris politikai kihívásoka szubszaharai régióban - rövid számvetés és jövőbetekintés. Afrika Tanulmányok, 2019/1-2, pp. 57-73.

- Srinivasan, R. - Sriram, M. S. (2003): Round Table Microfinance in India: Discussion. IIMB Management Review 15 (2), pp. 66-86.

- Tarrósy, I. (2010): Fenntartható Afrika - Lehetséges? In: Tarrósy, I. (szerk): Fenntartható Afrika. Publikon Kiadó, Pécs. pp.13-30.

- Tarrósy, I. (2016): Afro-ázsiai dinamikák. Tanulmányok ázsiai államok afrikai szerepvállalásairól. Publikon Kiadó, Pécs.

- Wright, G.A. (1999): „Vulnerability, Risks, Assets and Empowerment - The Impact of Microfinance on Poverty Alleviation“, MicroSave-Africa \& Uganda Women's Finance Trust, Kampala 


\section{English Abstract}

\section{Role of Self-Organizing Groups in the Ugandan Financial System}

Groups organized on the basis of voluntary cooperation play a significant role in the financial systems of subSaharan African countries. Following the success of the cooperative movement and the Grameen model, self-organized microfinance organizations have spread across the continent. In our study, we examine the role of self-organizing groups through the Ugandan example. According to a survey by the Central Bank of Uganda, there were about 1,000 active savings and credit unions and more than 70,000 financial self-help groups in the country in 2018. Although savings and credit cooperative organizations are sometimes influenced by the politics, they still play a significant role in poverty reduction.

\section{A szerzőkről}

Dr. Vasa László a Külügyi és Külgazdasági Intézet vezetô kutatója és főtanácsadója, valamint a Széchenyi István Egyetem kutatóprofesszora; több külföldi egyetem vendégprofesszora Kazahsztánban és Japánban, a Külügyi Szemle felelös szerkesztöje.

Vida Imre a gödölöi Szent István Egyetem Gazdaság- és Társadalomtudományi Karán szerzet† közgazdász oklevelet. Jelenleg a Szent István Egyetem Gazdálkodás- és Szervezéstudományok Dokłori Iskolájának dokłorandusz hallgatója. Nagy jártassággal rendelkezik a nemzetközi, különösen az afrikai pénzpiacok elemzésében, a pénzügyi sikerek tényezôiröl 2010-ben könyvet irt.

\section{About the Authors}

László Vasa is the senior researcher and chief advisor of the Institute for Foreign Affairs (Hungary) and research professor of the Széchenyi István University; visiting professor of Kazakh and Japanese universities, acting editor-in-chief of the Külügyi Szemle (Foreign Policy Review).

Imre Vida graduated as economist at Szent István University, School of Economics and Social Sciences. He is currently doctoral student of Szent István University's Doctoral School of Management and Business Administration Sciences, having great expertise in the analysis of international, especially African financial markets. He wrote a book on the factors of financial success in 2010

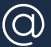

laszlo.vasa@ifat.hu

info@vidaimre.hu 